BSA 腎炎における urokinase, ancrod の投与効果

\author{
井田＼cjkstart隆* 小坂 佳子* 白木 正紀* \\ 吉村吾志夫* 栗山廉二郎* 戸村 成男* \\ 出浦 照国* 阿部 恒男* 武内重五郎*
}

\title{
The effect of urokinase and ancrod on acute BSA induced nephritis in rabbits
}

\author{
Takashi IDA*, Yoshiko OSAKA*, Masanori SHIRAKI*, \\ Ashio YOSHIMURA*, Renjiro KURIYAMA*, Shigeo TOMURA*, \\ Terukuni IDEURA*, Tsuneo ABE* and Jugoro TAKEUCHI*
}

Key words : BSA nephritis, urokinase, ancrod, intravascular coagulation

The role of intravascular coagulation in the progression of immune complex induced nephritis (BSA nephritis) was examined in the albino rabbits, and the effects of urokinase and ancrod were tested.

Non-treated group revealed hyperfibrinogenemia, high level of serum FDP and low plasminogen activator activity accompanying endocapillary proliferation after BSA treatment.

By daily infusion of urokinase $(3,000 \mathrm{U} /$ day $)$, the activity of plasminogen activator was conserved and the glomeruli showed more mild lesions than that of non-treated group.

By ancrod infusion (2U/kg/day; iv), the degree of endocapillary proliferation decreased accompanying hypofibrinogenemia.

These results suggest that intravascular coagulation plays an important role of BSA nephritis.

はじめに

ウシ血清アルブミン (bovine serum albumin : BSA）投与によるイエウサギ（以下ウサギ）実
験腎炎を対象とし，腎炎の発症・進展におよほ す糸球体血管内凝固の意義を検討し，さらに urokinase (UK), ancrod の投与効果屯検索し た。

* 東京医科歯科大学第二内科〔干113 東京都文京区湯島1-5-45〕, The Second Department of Internal Medicine, Tokyo Medical and Dental University, Tokyo, Japan. 


\section{I. 方 法}

体重3.0 3.5 kg のウサギを用い，BSA $3 \mathrm{mg}$ と complete Freund's adjuvant で感作したの ち, 合計750mgの BSA を 2 回に分け静脈内投 与し，コントロール群とした $(9 \text { 羽 })^{1)}$. また， 同様操作のほか，連日 UK 3,000U (i.v.) の投 与を行った群を UK 群 ( 9 羽), BSA 投与開 始日に $0.5 \mathrm{U} / \mathrm{kg}$ とその 1 時間後に $1 \mathrm{U} / \mathrm{kg}$ ，そ の後は連日 $1 \mathrm{U} / \mathrm{kg} \times 2$ の ancrod を投与した群 を ancrod 群 (5 羽) とした. 凝血学的検査は 未処置時，14日目前後に採取した血液を用い た。検査項目は血漿 fibrinogen (Fbg), 血中 FDP, euglobulin lysis area (ELA) あるいは euglobulin lysis time (ELT), streptokinase 加 euglobulin lysis area (Eug + SK) (標準平板 法 : Std, 加熱平板法 : Htd), PT, PTT, serial thrombin time (STT) である.

腎組織学的検討は14日目前後に採取した検体 を用い，おもに光顕所見で行い，endocapillary proliferation, extracapillary proliferation, capillary thrombosis, interstitial cell infiltration, vascular thrombosis それぞれの項目を，0度； なし，0.5度；所見を認めるが疑わしい， 1 度； 軽度， 2 度 ; 中等宰， 3 度 ; 高度に分類した。

\section{II. 成 績}

Fbg はコントロール，UK 群で BSA 投与後 に有意の増加を呈した。一方，ancrod 群は有意 に低下した（図1).PTはコントロール群では 一定の変化はなく，UK 群では短縮，ancrod 群 で延長と 3 群で異なった動きがみられた。 PTT はコントロール群で有意の（ $\mathrm{p}<0.05 ）$ 延長化 が生じたが，他の 2 群では一定の変化は認めら れなかった．FDPは 3 群すべてに BSA 投与 後の増加傾向が生じたが，統計的に有意であっ たのはコントロール群のみであった。

ELT あるいは ELA で測定した plasminogen activator 活性は，コントロール群で有意の（ $\mathrm{p}$ ＜0.025）低下が生じたが，UK, ancrod 群は一 定傾向を呈さなかった．Eug+SK(Std) で測定 した plasminogen proactivator 活性は，UK, ancrod 群で BSA 投与後に有意の増加を示し, コントロール群は一定の傾向は認めなかった。

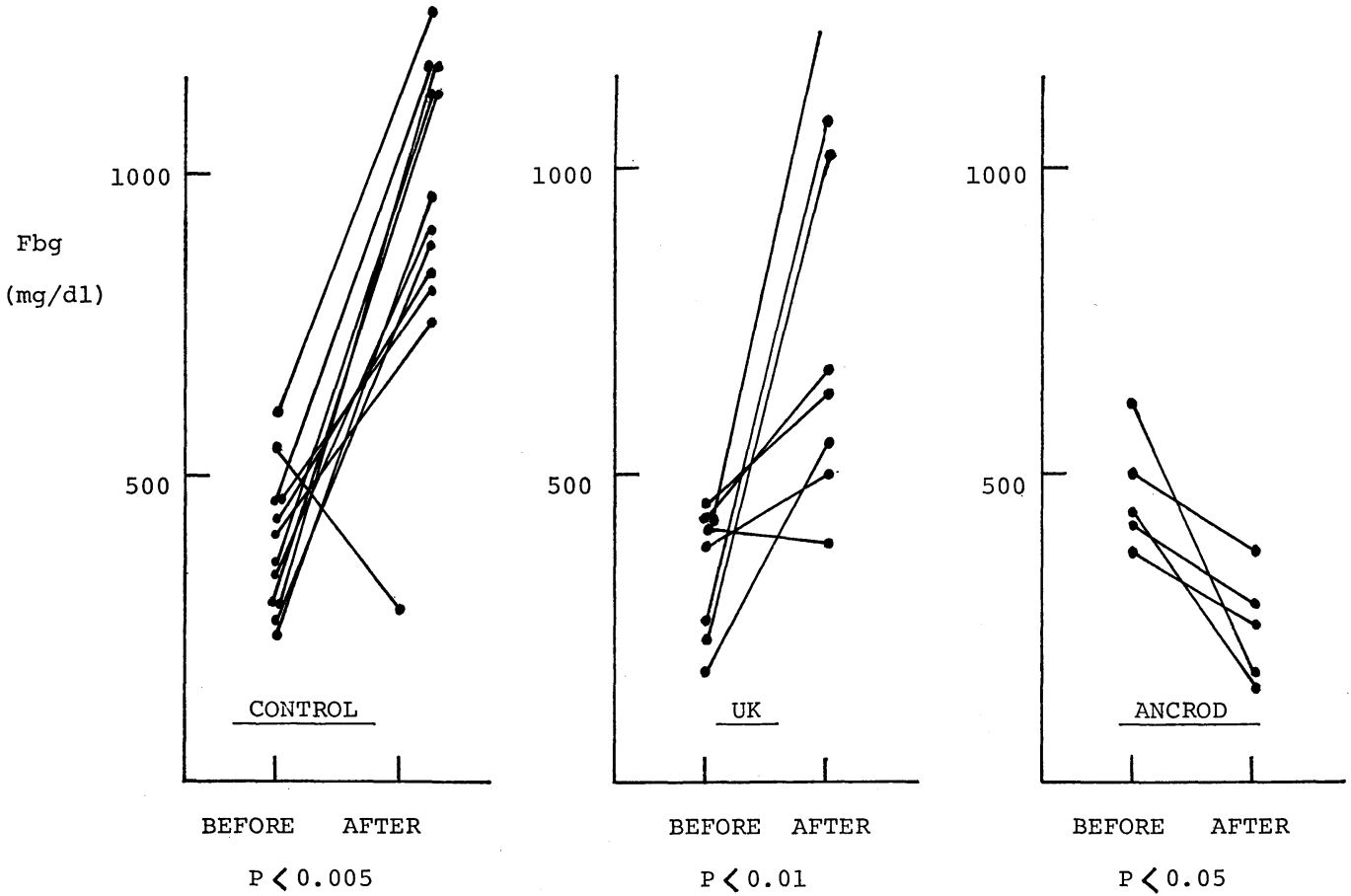

Fig. 1 Changes of plasma fibrinogen after BSA treatment 
Table 1 Histological changes

\begin{tabular}{|c|c|c|c|c|c|c|c|c|c|c|c|c|c|c|c|}
\hline \multirow[b]{2}{*}{ Endocapillary proliferation } & \multicolumn{5}{|c|}{ Control } & \multicolumn{5}{|c|}{ UK-treated } & \multicolumn{5}{|c|}{ Ancrod-treated } \\
\hline & 0 & 0 & 2 & 6 & 1 & 0 & 0 & 3 & 6 & 0 & 0 & 1 & 3 & 1 & 0 \\
\hline Extracapillary proliferation & 6 & 3 & 0 & 0 & 0 & 6 & 2 & 1 & 0 & 0 & 5 & 0 & 0 & 0 & 0 \\
\hline Capillary thrombosis & 3 & 3 & 2 & 1 & 0 & 1 & 5 & 3 & 0 & 0 & 2 & 2 & 1 & 0 & 0 \\
\hline Interstitial cell prolif. & 6 & 1 & 2 & 0 & 0 & 7 & 0 & 2 & 0 & 0 & 5 & 0 & 0 & 0 & 0 \\
\hline Vascular thrombosis & 4 & 2 & 1 & 2 & 0 & 1 & 1 & 7 & 0 & 0 & 4 & 1 & 0 & 0 & 0 \\
\hline Histological grade & 0 & 0.5 & 1 & 2 & 3 & 0 & 0.5 & 1 & 2 & 3 & 0 & 0.5 & 1 & 2 & 3 \\
\hline
\end{tabular}

Table 2 Summary of coagulopathic examination

\begin{tabular}{l|c|c|c}
\hline & Control & UK-treated & Ancrod-treated \\
\hline Fibrinogen & $\uparrow$ & $\uparrow$ & $\downarrow$ \\
FDP & $\uparrow$ & $\nearrow$ & $\nearrow$ \\
PT & $\rightarrow$ & $\downarrow$ & $\uparrow$ \\
PTT & $\uparrow$ & $\uparrow$ & $\nearrow$ \\
Plasminogen activator & $\downarrow$ & $\rightarrow$ & $\rightarrow$ \\
Plasminogen proactivator & $\rightarrow$ & $\uparrow$ & $\uparrow$ \\
Plasminogen & $\rightarrow$ & $\nearrow$ & $\rightarrow$ \\
\hline$\uparrow$ increase $\rightarrow$ no change & \multicolumn{1}{c}{ tendency of increase } & $\downarrow$ decrease
\end{tabular}

Plasminogen 量を反映する $\mathrm{Eug}+\mathrm{SK}(\mathrm{Htd})$ は 3 群いずれあ一定の変化を生じなかった。な お，STTは 3 群すべて有意の延長がみられた.

腎組織所見は, endocapillary proliferation の 程度がコントロール群で平均1.9, UK 群で1.7, ancrod 群で1.1と UK, ancrod 群での軽快傾向 をみたが，統計的には有意でなかった，Extracapillary proliferation は平均值がコントロール 群; 0.22, UK 群; 0.17, ancrod 群; 0であ ったが，有意差はなかった. Capillary thrombosis はコントロール, UK 群いずれも平均 0.61, ancrod 群; 0.4であった. Vascular thrombosis はコントロール群；0.72, UK群; 1.3, ancrod 群；0.01であった（表 1).

\section{III. 考 察}

現在，ヒト腎炎で血管内凝固が 1 つの増悪因 子とされる根拠としては，1）形態学的に fibrin
体が腎糸球体に見出される，2）血管内凝固の 反映之考えられる FDP が血中, 尿中で増加し ている ${ }^{233)}$ ，3）ある種腎疾患患者で radioisotope でラベルした Fbg, 血小板 の 血中消失率が高 く，しかむ腎への摄取が多(4)5) などの事実が ある。

凝血学的検查では（表 2), コントロール群 飞投与後の高 Fbg 血症, PTT 延長, 高 FDP 血症, plasminogen activator 活性低下が生じ, intravascular coagulation の存在が推測される. Ancrod 投与により，BSA 投与後むむしろ Fbg は低下し, plasminogen activator を含む線溶能 は保持された。なお，PT の延長が認められた が，おむに Fbg 低下のための延長と考える. UK 投与では, 高 Fbg 血症は生じたが, FDP は不変, plasminogen activator 活性の保持, proactivator 活性の増加と ancrod 群と同様に線 溶能の保持が認められた. 
以上の結果から, UK, ancrod は凝血学的に BSA 投与後の consumption coagulopathy の出 現を防いだことが推察される. UK は FDP 増 加が少なかったてとからあ, 早期の血栓溶解に より，血栓形成が生ずるより強い血栓形成傾向 を予防し, ancrod はその脱 Fbg 酵素としての 薬理作用により，fibrin 血栓の形成を抑制した と考えられる。

さらに，統計的には有意ではなかったが， UK, ancrod 群での腎組織障害の程度の軽快傾 向が観察されたととは，腎血管内凝固が BSA 腎炎における腎障害の 1 つの因子であるととが 示唆される。

$$
\text { ま と め }
$$

BSA 腎炎を用い，腎血管内血液凝固の意義 を凝血学的, 腎組織学的に検討した. BSA 投 与により高 Fbg 血症, 高 FDP 血症, 線溶能 低下を伴う腎炎が生じた。 UK, ancrod 投与が 凝血学的および腎組織学的に改善傾向を生じた ことは，BSA 腎炎における血管内凝固の関与 が示唆される.

\section{文献}

1）井田 隆，他： BSA 腎炎の urokinase 投与 効果の検討. J. Med. Enzymol., 3；301 310, 1979.

2) Michielsen, P., et al.: Significance of urinary excretion of fibrin degradation products during treatment of glomerulonephritis. Clin. Nephrol., 5; 105 113, 1976.

3) Tomura, S., et al.: Glomerulonephritis. Proceedings International Symposium. Tokyo, Univ. of Tokyo Press, pp. 393 409, 1979.

4) Clark, W.F., et al. : Intrarenal platelet consumption in the diffuse proliferative nephritis of systemic lupus erythematosus. Clin. Sci. Mol. Med., 49; 247 252, 1975.

5) Wardle, E. N.: A study of intravascular coagulation in immune complex glomerulonephritis by use of ${ }^{131}$ I-labelled fibrinogen and ${ }^{125} \mathrm{I}$-labelled antigen. Clin. Sci. Mol. Med., 45; 35 50, 1973.

\section{○葉酸研究の完全なる集大成！
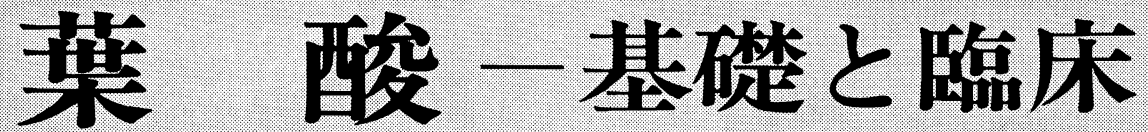

編集 京都大学内科教授 内野治人 岐阜歯科大学内科教授 外林秀紀 専門医18氏分担執筆

A 5 判 484頁 図172 表104 定価9,800円(干200円)

巴101 東京都千代田区神田多町 2-11 科 学 評 論 社 振替口座東京7-102026 